\title{
Intrathoracic Thermochemoradiotherapy for the Treatment of Locally- Advanced Malignant Pleural Mesothelioma
}

\author{
TOMOKO ITAZAWA*, KATSUYUKI KARASAWA, HIDEMASA KAWAMURA, \\ NAHOKO HANYU, YUZURU NIIBE ${ }^{1}$, YOSHIAKI TANAKA ${ }^{2}$ \\ Department of Radiology, Tokyo Metropolitan Komagome Hospital \\ Honkomagome, Bunkyo-ku, Tokyo, 113-8677, JAPAN \\ ${ }^{1}$ Department of Radiology, Kitasato University School of Medicine \\ Kitasato, Sagamihara-city, Kanagawa, 228-8555, JAPAN \\ ${ }^{2}$ Department of Radiology, Nihon University School of Medicine \\ Ohyaguchi, Itabashi-ku, Tokyo, 173-8610, JAPAN
}

Abstracts : Malignant pleural mesothelioma (MPM) is considered to carry very poor prognoses and reported surgical results revealed median survival time to be less than one year for UICC-stage I to III. Instead of surgery, we performed thermoradiotherapy combined with chemotherapy using platinum compounds into the pleural cavity for the treatment of this disease. We experienced 8 cases of UICC-stage I to III MPM and 3 of them got good response and survival time of more than 2 years, respectively (median survival time was 14.1 months). This treatment method might be well tolerated by the patient with good quality and quantity of life. Furthermore, the amount of the pleural effusion was controlled in most patients. As radical aggressive treatment carries considerable risk of mortality and morbidity, this organ-conserving trimodal therapy might be an alternative treatment modality.

Key Words : chemothermotherapy, hyperthermia, malignant pleural mesothelioma

\section{Introduction}

Malignant pleural mesothelioma (MPM) is considered to carry vcry poor prognoses and reported surgical results revealed median survival time to be less than one year for UICC-stage I to III ${ }^{1-5)}$. However, it is considered that the only curative treatment is complete surgical resection which can be life threatening. Instead of surgery, we performed thermoradiotherapy combined with chemotherapy into the pleural cavity for the treatment of this disease ${ }^{6}$. Since 1995 , we have experienced 8 cases and some of them obtained good response and favorable prognosis. In this paper, we presented our preliminary results and discussed about the problems.

Received 5 January 2004, Accepted 21 June 2004. ${ }^{*}$ Corresponding author, Tel : +81-3-3823-2101; Fax: +81-3-3824-1552;

E-mail : t_itaume@med.yokohama-cu.ac.jp 
Table I patient's characteristics

\begin{tabular}{|c|c|c|c|c|c|c|}
\hline No & age & sex & side & PS & UICC-TNM & UICC-stage \\
\hline 1 & 64 & M & R & 2 & T3N1M0 & III \\
\hline 2 & 54 & F & R & 1 & T1N0M0 & I \\
\hline 3 & 48 & M & L & 1 & T2N2M0 & III \\
\hline 4 & 77 & F & R & 1 & T1N0M0 & I \\
\hline 5 & 67 & M & L & 1 & T1N0M0 & I \\
\hline 6 & 76 & F & L & 1 & T3N1M0 & III \\
\hline 7 & 85 & M & L & 2 & T3N2M0 & III \\
\hline 8 & 51 & M & R & 2 & T3N2M0 & III \\
\hline med & 65.5 & & & & & \\
\hline
\end{tabular}

$\mathrm{R}$ : right , L : left

Table II treatment protocol

Eligibility criteria

Age between 20 and 85

PS 0-3

No concurrent chemo-and/or radiotherapy

$\mathrm{WBC} \geqq 2,500$, Plt $\geqq 100,000$

No severe hepatic nor renal dysfunction

No severe infection nor heart disease that precludes this treatment

Treatment Schedule

Concurrent thermo-radio-and intrathoracic chemotherapy once a week

Radiotherapy for hemithorax $2 \mathrm{~Gy} /$ fr by $10 \mathrm{MV}$ photon beam through AP-PA technique just before chemotherapy

Chemotherapy CDDP/CBDCA

CDDP $50 \mathrm{mg} /$ body, or CBDCA $450 \mathrm{mg} /$ body

infuse just before hyperthermia treatment

Hyperthermia (RF Capacitive heating)

AP-PA technique, duration 45-60min.

\section{Patient \& Method of Treatment}

\section{Patient characteristics}

From 1995 to 2002, there were 8 patients with UICC-stage I to III MPM who were treated with thermoradiotherapy combined with chemotherapy into the pleural cavity at Tokyo Metropolitan Komagome Hospital. Among this 8 patients, three were reported previously ${ }^{6)}$. Patient characteristics are shown in table 1.

Patient's age ranged from 48 to 85 years (median 65.5). There were 5 males and 3 females. There were 4 left-sided tumors and 4 right-sided tumors. The Zubrod performance status at the beginning of radiotherapy was 1 in 5 cases and 2 in 3 cases. All patients were diagnosed histologically as malignant pleural mesothelioma. Pretreatment UICC-stageI was in 3 cases, stageIII in 5cases.

Method of Treatment

Our treatment protocol is listed in Table 2. We mentioned the protocol in detail in the previous paper ${ }^{6)}$. 
We administered thermochemo-radiotherapy once weekly until pleural effusion almost vanished. We did not give any further adjuvant treatment until disease progression.

\section{Hyperthermia}

Hyperthermia was given using RF-capacitive heating apparatus (Thermotron RF-8). Hyperthermia was given once per week for about 60 minutes (median 3.5 times). The electrodes were placed in front and back of the patient. The used electrodes ranged from $25 \mathrm{~cm}$ to $30 \mathrm{~cm}$ in diameter. Overlay bolus was used to reduce the edge effect. Thermometry was performed by inserting thermocouples directly into the tumor for 2 patients, into chest wall for 4 patients, effusion itself for 1 patient or put on the patient's skin for 1 patient.

\section{Chemotherapy}

Chemotherapy was administered into thoracic space through the Trocker tube. Chemotherapeutic agents administered were Cisplatinum (CDDP) for 4 patients, Carboplatinum (CBDCA) for 3 patients, both CDDP and CBDCA for 1 patient. The dose of CDDP was $50 \mathrm{mg} /$ body, and the dose of CBDCA was $450 \mathrm{mg} /$ body.

\section{Radiotherapy}

Radiotherapy was administered with 10MV photon beams generated by a linear accelerator. In principle, MPMs are disseminated to the entire pleural cavity, so the field should cover the entire hemithorax. Because lung tissue is radiosensitive, radiotherapy was administered once weekly on the very day of hyperthermia and just before thermochemotherapy. The total radiation dose ranged from 2 to $10 \mathrm{~Gy}$ and the fraction size was 1 or $2 \mathrm{~Gy}$ (median $7 \mathrm{~Gy} / 3.5 \mathrm{fr}$ ).

\section{Data analysis}

We analyzed this data in June 2003. The response of treatment was assessed by CT. The criteria of response was based on those of Vogelzang and the colleagues ${ }^{7}$. A complete response (CR) was defined as complete absence of disease. A partial response (PR) was defined as $\geqq 50 \%$ reduction from baseline of the sum of the products of perpendicular diameters of bidimensionally measurable disease or $\geqq 30 \%$ decrease in the sum of the greatest diameters of unidimensionally measurable lesions. $\Lambda$ progressive disease (PD) was defined as $\geqq 50 \%$ increase from baseline of the sum of the products of perpendicular diameters of bidimensionally measurable disease or $\geqq 25 \%$ increase in the sum of the greatest diameters of unidimensionally measurable lesions. A stable disease (SD) was disease that did not qualify for CR, PR, nor PD. Analysis of overall survival was calculated using the Kaplan- Meier method.

\section{Results}

The results are shown in table 3 . Three cases could reach PR, another 3 was SD, and 2 was PD. Survival period ranged from 4.1 to 68.0 months, and the median survival time was 14.1 months (Fig1). Survival time is closely related to the response. All 3 PR cases survived more than 2 years whereas no patient whose response was SD or PD survived 2 years. 
After this treatment, we could decrease the amount of their pleural effusion in 6 of 8 patients and their performance status was improved, and all cases could discharge from the hospital.

As for complications, we experienced grade 4 thrombocytopenia in 1 case. We needed blood transfusion to the patient. No severe cardiac nor pulmonary toxicity has been observed.

Of all 8 patients, 7 patients died of respiratory disorder caused by intrathoracic recurrence and intractable pleural effusion. There were no patients who recurred either at biopsied site or at the site of Trocker tube was put. Three patients survived more than 2 years.

Table III treatment results

\begin{tabular}{|c|c|c|c|c|c|c|}
\hline No. & RT $(\mathrm{Gy} / \mathrm{fr})$ & $\mathrm{HT}$ & chemo & Tmax & response & $\begin{array}{c}\text { Survival period } \\
\text { (months) }\end{array}$ \\
\hline 1 & $2 / 1$ & 2 & $\mathrm{Cb}$ & $44.2 \mathrm{t}$ & $\mathrm{PR}$ & $68.0 / \mathrm{D}$ \\
\hline 2 & $8 / 4$ & 4 & $\mathrm{C}$ & $43.2 \mathrm{w}$ & $\mathrm{PR}$ & $27.4 / \mathrm{D}$ \\
\hline 3 & $10 / 5$ & 5 & $\mathrm{Cb}$ & $42.3 \mathrm{w}$ & $\mathrm{PR}$ & $27.1 / \mathrm{D}$ \\
\hline 4 & $6 / 3$ & 3 & $\mathrm{C}$ & $43.7 \mathrm{w}$ & $\mathrm{SD}$ & $14.1 / \mathrm{A}$ \\
\hline 5 & $10 / 5$ & 5 & $\mathrm{C} / \mathrm{Cb}$ & $40.1 \mathrm{~s}$ & $\mathrm{SD}$ & $7.6 / \mathrm{D}$ \\
\hline 6 & $6 / 3$ & 3 & $\mathrm{C}$ & $43.0 \mathrm{w}$ & $\mathrm{SD}$ & $6.5 / \mathrm{D}$ \\
\hline 7 & $3 / 3$ & 3 & $\mathrm{Cb}$ & $42.8 \mathrm{i}$ & $\mathrm{PD}$ & $6.5 / \mathrm{D}$ \\
\hline 8 & $10 / 5$ & 5 & $\mathrm{C}$ & $41.2 \mathrm{t}$ & $\mathrm{PD}$ & $4.1 / \mathrm{D}$ \\
\hline median & $7.0 / 3.5$ & 3.5 & & & & 14.1 \\
\hline
\end{tabular}

RT : radiotherapy, HT : hyperthermia, chemo : chemotherapeutic agents,

Tmax : maximum temperature, $\mathrm{t}:$ tumor, $\mathrm{w}$ : chest wall, $\mathrm{s}$ : skin, $\mathrm{i}:$ intrathoracic $\mathrm{C}$ : CDDP, $\mathrm{Cb}$ : CBDCA

$\mathrm{D}$ : dead, $\mathrm{A}$ : alive

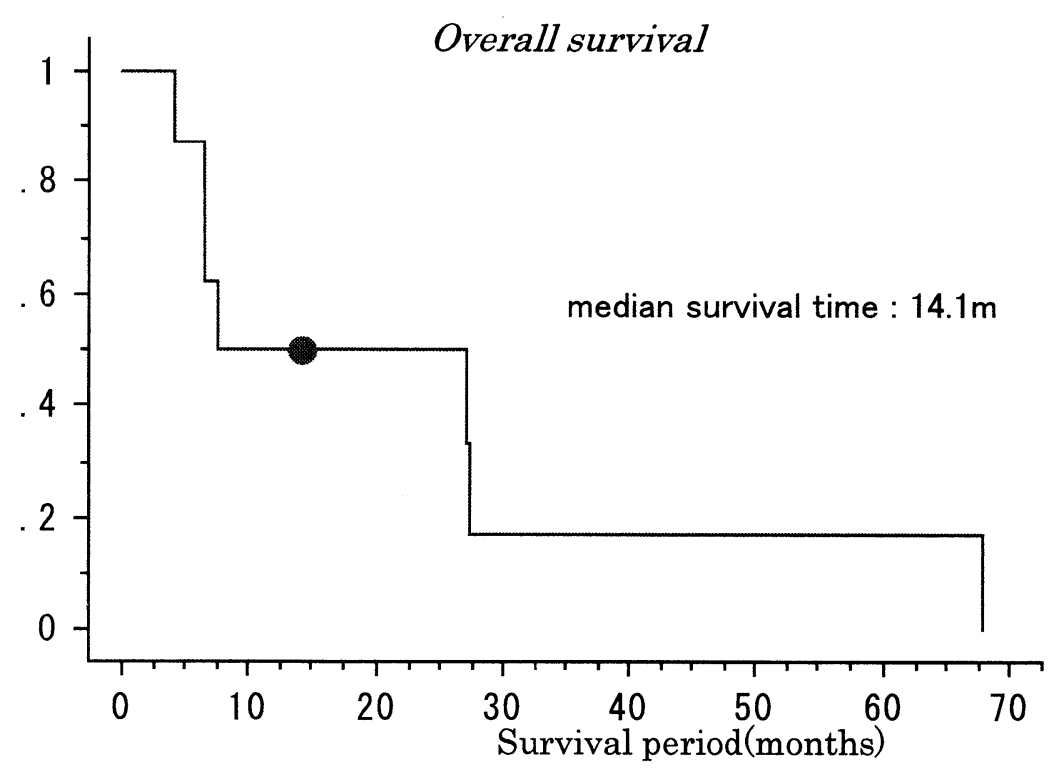

Fig. 1. Overall survival of all eight patients 


\section{Discussion}

The annual incidence and mortality rate of MPM were around 1 per 100,000 populations in the United States ${ }^{8}$. In Japan, they were certainly less than those of USA. Because of the rarity of the disease and its dismal prognosis, the standard treatment has not fully been established. But the incidence has been increasing gradually in recent years. Therefore, it is necessary to improve the treatment results.

As for the treatment of MPM, only possibly curative treatment is considered to be panpleuropneumonectomy ${ }^{1-5)}$, the MSTs of which are around 1 year, whereas radiation therapy ${ }^{9}{ }^{10)}$ or chemotherapy ${ }^{11)}$ is used only palliatively with dismal treatment results with the MST of around only several months. Recently, combined modality treatment approach has improved the treatment results ${ }^{12)}$. However, aggressive treatment will have high risk of morbidity and mortality, thus it is not entirely safe to say it is the standard treatment ${ }^{12)}{ }^{13)}$.

In recent years, chemotherapy might be administered intrathoracicly instead of intravenously to increase the drug concentration ${ }^{14)}$. Furthermore, hyperthermia might be added to promote the depth dose of the chemotherapeutic agents ${ }^{15)}$. We reported a case of extremely good response ${ }^{6}$, which suggested the thermal enhancement of chemotherapeutic agent (CBDCA) because of the bulk of the tumor and the response would not have been acquired with chemotherapy alone. van Ruth et al. reported the enhancing effect of hyperthermia ${ }^{16}$. Hyperthermia might be combined with chemotherapy for this kind of disease with otherwise dismal prognosis.

Regarding intrathoracic thermochemotherapy combined with surgery there have been other reports ${ }^{17-19)}$. In their cases there were a few hospital deaths but their median survival time and 5-year survival rate calculated from their data were 17 months and 7\%, respectively, which were quite similar to our survival curve. The meaning of surgical debulking needs to be tested because we treated relatively old patients.

Hyperthermia has been expected to have another usefulness of enhancing the inflammatory reactions caused by chemotherapeutic reaction, which results in the adhesion of pleural space. In fact, pleural effusion stopped in the majority of our cases and all cases could discharge from the hospital.

Although our median survival time was 14.1 months, 3 cases (37.5\%) survived more than 2 years, 1 case (12.5\%) survived more than 5 years, no patients died within 1 month and all patients could discharge from the hospital. Therefore, our treatment approach might well be an alternative approach for aggressive surgery though the number of patients is small.

Moreover, we will not give any further adjuvant treatment until disease progression. Therefore our approach is quite cost-effective and might be recommended for the future.

Concerning radiation therapy, we have been giving radiotherapy expecting that it will enhance the effect of chemotherapy and hyperthermia. Because of the radiosensitivity of the normal lung tissue, we restrict the radiation dose under $10 \mathrm{~Gy}$ in one course of the treatment. We need to test the efficacy of such low dose of radiation in a prospective trial.

For the future, we will have to analyze the prognostic factors and further optimize the treatment. 


\section{References}

1) Butchart E.G., Ashcroft T., Barnsley W.C., Holden M.P.: Pleuropneumonectomy in themanagement of diffuse malignant mesothelioma of the pleura : Experience with 29 patients. Thorax, 31: 15, 1976.

2) Antman K.H., Pass H.I., Schiff P.B.: Benign and malignant mesothelioma. "Cancer Principles and Practice of Oncology”. Ed. De Vita VTJ, Hellman S., Rosenenberg S.A., Philadelphia, PA : Lippincott, Williams \& Wilkins, pp1943-1969, 2001.

3) Brenner J., Sordillo P.P., Magill G.B., Golbey R.B.: Malignant mesothelioma of the pleura. Cancer, 49: 2431-2435, 1982.

4) Alberts A.S., Falkson G., Goedhals L., Vorobiof D.A., Van der Merwe C.A. : Malignant pleural mesothelioma : a disease unaffected by current therapeutic maneuvers. J Clin Oncol, 6: 527-535, 1988.

5) Boutin C., Rey F., Gouvernet J., Viallat J.R., Astoul P., Ledoray V.: Thoracoscopy in pleural malignant mesothelioma.: A prospective study of 188 consecutive patients. Cancer, $72: 394-404,1993$.

6) Karasawa K., Kaizu T., Niibe Y., Ishikawa H., Okamura T., Tanaka Y. : Intrathoracic thermochemoradiotherapy for the treatment of locally-advanced malignant pleural mesothelioma -Treatment protocol and report of the three cases. Jpn J Hyperthermic Oncol, 17: 45-52, 2001.

7) Vogelzang N.J., Rusthoven J.J., Symanowski J., Denham C., Kaukel E., Ruffie P., Gatzemeier U., Boyer M., Emri S., Manegold C., Niyikiza C., Paoletti P.: Phase III study of pemetrexed in combination with cisplatin versus cisplatin alone in patients with malignant pleural mesothelioma. J Clin Oncol, $21:$ 2636-2644, 2003.

8) Ho L., Sugarbaker DJ., Skarin AT.: Malignant pleural mesothelioma. "Thoracic Oncology, Kluwer Academic Publishers". Ed. Ettinger D.S., Boston, pp327-373, 2001.

9) Bissett D., Macbeth F.R., Cram I. : The role of palliative radiotherapy in malignant mesothelioma. Clin Oncol (R Coll Radiol), 3 (6) : 315-317, 1991.

10) Ball D.L., Cruickshank D.G.: The treatment of malignant mesothelioma of the pleura: review of a 5-year experience, with special reference to radiotherapy. Am J Clin Oncol, 13: 4-9, 1990.

11) Chahinian A.P., Antman K., Goutsou M., Corson J.M., Suzuki Y., Modeas C., Herndon J.E. 2nd., Aisner J., Ellison R.R., Leone L. : Randomized phase II trial of cisplatin with mitomycin or doxorubicin for malignant mesothelioma by the Cancer and Leukemia Group B. J Clin Oncol, 11: 1559-1565, 1993.

12) Sugarbaker D.J., Strauss G.M., Lynch T.J., Richards W., Mentzer S.J., Lee T.H., Corson J.M., Antman K.H. : Node status has prognostic significance in the multimodality therapy of diffuse, malignant mesothelioma. J Clin Oncol, 11: 1172-1178, 1993.

13) Sugarbaker D., Harpole D., Healey E.: Multimodality treatment of malignant pleural mesothelioma (MPM) : results in 94 consecutive patients. Proceedings of the American Society of Clinical Oncology, 14 : A-1083, 356, 1995.

14) Rusch V.W., Figlin R., Godwin D., Piantadosi S.: Intrapleural cisplatin and cytarabine in the management of malignant pleural effusions : a Lung Cancer Study Group trial. J Clin Oncol, 9: 313-319, 1991.

15) Ratto G.B., Civalleri D., Esposito M., Spessa E., Alloisio A., De Cian F., Vannozzi M.O.: Pleural space perfusion with cisplatin in the multimodality treatment of malignant mesothelioma : a feasibility and pharmacokinetic study. J Thorac Cardiovasc Surg, 117 : 759-765, 1999.

16) van Ruth S., Baas P., Haas R.L., Rutgers E.J., Verwaal V.J., Zoetmulder F.A. : Cytoreductive surgery combined with intraoperative hyperthermic intrathoracic chemotherapy for stage I malignant pleural mesothelioma. Ann Surg Oncol, 10 : 176-182, 2003.

17) de Bree E., van Ruth S., Baas P., Rutgers E.J., van Zandwijk N., Witkamp A.J., Zoetmulder F.A.: Cytoreductive surgery and intraoperative hyperthermic intrathoracic chemotherapy in patients with malignant pleural mesothelioma or pleural metastases of thymoma. Chest, 121: 480-487, 2002. 
Intrathoracic Thermochemoradiotherapy for MPM • T. Itazawa et al.

18) Monneuse O., Beaujard A.C., Guibert B., Gilly F.N., Mulsant P., Carry P.Y., Benoit M., Glehen. : Long-term results of intrathoracic chemohyperthermia (ITCH) for the treatment of pleural malignancies. $\mathrm{Br}$ J Cancer, $88: 1839-1843$, 2003.

19) Yellin A., Simansky D.A., Paley M., Refaely Y.: Hyperthermic pleural perfusion with cisplatin : early clinical experience. Cancer, 92: 2197-2203, 2001. 


\title{
当科における悪性胸膜中皮腫に対する 温熱化学放射線療法の治療成績
}

板澤朋子 ${ }^{1}$ - 唐澤克之 ${ }^{1}$ - 河村英将 ${ }^{1}$

羽生菜穂子 ${ }^{1}$ ・新 部 譲 2 田中良明 ${ }^{3}$

\author{
1 東京都立駒込病院放射線診療科 \\ 2 北里大学医学部放射線医学教室 \\ ${ }^{3}$ 日本大学医学部放射線科
}

\begin{abstract}
要旨：悪性胸膜中皮腫は非常に予後不良の疾患とされ, Butchart 分類の II 期以上での手術成績は 1 年以下と報告されている. 我々は手術療法の代わりに, プラチナ系抗癌剤胸腔内投与を併用した温熱放 射線療法を施行している. 我々は悪性胸膜中皮腫 8 例 (UICC-TNM 分類 I 期 3 例, III 期 5 例) を経験し, うち 3 例に生存期間 2 年以上という良好な結果を得た (生存期間の中央值 14.1 ケ月). この治療方法は患 者にとって耐容し得るものでありかつ胸水を制御でき, 良好な QOL を維持できるものと思われる. 侵襲 的な治療法は治療関連死や合併症を起こす危険をはらむため, 臟器温存的なこの 3 者併用療法は, その代 替療法となる可能性がある.
\end{abstract}

